\title{
Ten health stories that mattered: Jan. 13-17
}

- Google's health-related ads violate Canadian privacy rights, found an investigation by the Office of the Privacy Commissioner of Canada. Google targets users with healthrelated ads based on the health websites they visit. "We are pleased Google is acting to address this problem," Interim Privacy Commissioner Chantal Bernier said in a news release. "Most Canadians consider health information to be extremely sensitive. It is inappropriate for this type of information to be used in online behavioural advertising."

- Canada found an extra half-million flu shots it could buy to meet growing demand across the country. Still, clinics are running out of the vaccine in some areas, including the Lower Mainland and Vancouver Island in British Columbia.

- The H5N1 bird flu virus is not likely to spread in Canada, according to an official from the World Health Organization. Concern had been raised after the recent death of an Alberta nurse from the virus, which is not easily transmitted between humans. The nurse had recently travelled to China.
- Patients should know more about the cost of their health care, according to Windsor Regional Hospital CEO David Musyj. In a report to the hospital's board, Musyj suggested that patients receive summaries of all charges covered under the Ontario Health Insurance Plan.

- The sale and use of electronic cigarettes among youth are becoming a concern in New Brunswick, says the province's deputy chief medical officer of health. "The flavours are attractive. They get used to holding a cigarette. The cigarette looks pretty much like the tobacco cigarette. And it's just easy then for them to move on to using the ones with nicotine in the future, and eventually, perhaps even the tobacco products," Dr. Denis Allard told CBC News.

- Minimum wage should be raised to \$14 in Ontario, a group of doctors and nurses urged the provincial government. The health care professionals, members of Health Providers Against Poverty, referred to poverty as one of the biggest barriers to good health.

- Harm-reduction programs are no longer illegal in Abbotsford, British
Columbia. The city had been one of only three in the province that still had restrictions on services such as methadone clinics, needle exchanges and safe-injection sites.

- Alberta is considering making flu shots mandatory for health care workers, prompted by statistics out of Calgary showing that less than half of health workers received the influenza vaccine this year. A recent ruling in British Columbia made it mandatory for health care workers to either get a flu shot or wear a mask when treating patients.

- Health information of 1000 patients was faxed to wrong numbers in Saskatchewan, according to the province's privacy commissioner. Most of the cases involved personal medical records being faxed to outdated physician phone numbers.

- Five hospitals will be closed and replaced with a new acute care centre in Southern Ontario, announced Health Minister Deb Matthews. The government is providing \$26.2 million to develop plans for the new hospital. — Roger Collier, CMAJ

CMAJ 2014. DOI:10.1503/cmaj.109-4707 